\title{
IMPLEMENTASI SISTEM PAKAR GUNA MENDIAGNOSA PENYAKIT CACAR AIR DENGAN METODE BAYES
}

\author{
Eko Mulya Chandra $^{1}$, Yulindon $^{2}$, Rahmat Hidayat $^{3}$ \\ Teknologi Rekayasa Perangkat Lunak/Teknologi Informasi, Politeknik Negeri Padang ${ }^{1}$ \\ Email : ekomulyachandra99@email.com ${ }^{1}$, yulindon@pnp.ac.id ${ }^{2}$,rahmat@pnp.ac.id ${ }^{3}$
}

\begin{abstract}
ABSTRAK
Perkembangan teknologi dari tahun ke tahun berkembang dengan pesat disegala aspek kehidupan. Salah satu aspek tersebut yaitu Kesehatan. Dengan teknologi saat ini kita dapat mengetahui penyakit cacar air yang kita derita atau orang lain tanpa perlu konsultasi ke dokter dengan aplikasi sistem pakar. Karena masih banyak orang yang belum mengetahui gejala-gejala cacar air.Sehingga dengan dibuatnya sistem pakar ini orang awam dapat mampu mendeteksi adanya penyakit pada dirinya atau orang lain berdasarkan gejala-gejala yang dirasakan dengan menjawab pertanyaan seperti halnya berkonsultasi ke dokter.Sistem pakar ini menggunakan metode bayes. Dengan metode bayes dapat menunjukan besarnya nilai hasil kepercayaan terhadap hasil diagnosa.
\end{abstract}

Kata Kunci: Cacar air,Metode Bayes,Sistem Pakar

\begin{abstract}
The development of technology from year to year is growing rapidly in all aspects of life. One such aspect is Health. With current technology, we can find out the chickenpox we are suffering from or other people without the need to consult a doctor with the application of an expert system. Because there are still many people who do not know the symptoms of chickenpox. So that with this expert system made ordinary people can be able to detect the disease in themselves or others based on the symptoms felt by answering questions such as consulting a doctor. This expert system uses Bayes method. With Bayes method can show the value of the results of confidence in the diagnosis
\end{abstract}

Keywords: Bayes Method,Chickenpox,Expert System

\section{PENDAHULUAN}

Pertambahan jumlah penduduk yang relatif cukup cepat, diiringi pertambahan usia harapan hidup manusia, menambah jumlah penduduk di dunia. Diperkirakan jumlah penduduk dunia saat ini berjumlah lebih 5 milyar orang.Dengan jumlah penduduk yang sebesar itu bertambah komplek pula permasalahan yang ditimbulkan, seperti sandang, pangan, papan, kesehatan dan lain sebagainya (Hutagalung, Kunci-:, Bayes, \& Pakar, 2015).

Terutama dalam hal masalah kesehatan semakin banyak jumlah penduduk didunia semakin banyak juga jumlah penderita suatu penyakit serta bertambah pula jenis penyakit. Salah satu contoh penyakit yang saat ini yang sering kita jumpai adalah penyakit cacar air . 
Penyakit ini banyak menyerang anak-anak tapi tidak menutup kemungkinan orang dewasa juga tidak bisa terkena penyakit ini.

Penyakit cacar air merupakan salah satu penyakit menular yang dapat menyerang siapa saja, terutama mereka yang belum mendapatkan imunisasi. Berdasarkan data Australia menunjukkan, $83 \%$ dari anak-anak yang terinfeksi oleh cacar air berumur $10-14$ tahun. Di Australia ada sekitar 240.000 kasus,

1.500 rawat inap dan sekitar 7 kematian setiap tahun akibat cacar air(Warini \& Sunyoto, 2017).

Penyakit ini bisa dibilang sulit untuk mendiagnosis nya oleh karena itu pasien harus melibatkan dokter secara langsung dan nantinya doketer akan menganalisa secara manual. Sehingga tidak menutup kemungkinan terjadinya kesalahan diagnosis penyakit yang dialamai pasien.Dengan perkembangan zaman pada saat ini yang hampir semua bidang kehidupan ikut berkembang juga. Tidak terlepas bidang kesahatan yang mendukung kegiatan operasionalnya menggunakan komputerisasi. Salah satu contohnya yaitu sistem pakar. Secara umum, sistem pakar (expert system) adalah sistem yang berusaha mengadopsi pengetahuan manusia ke komputer, agar komputer dapat menyelesaikan masalah seperti yang biasa dilakukan oleh para ahli (Nasution \& Khairuna, 2017).

Oleh karena itu penulis membuat sebuah rancangan aplikasi sistem pakar yang dapat mendiagnosa suatu penyakit.Sistem ini terbatas pada penyakit cacar air. Karena masih banyak orang yang belum mengetahui gejala-gejala cacar
air.Sehingga dengan dibuatnya sistem pakar ini orang awam dapat mampu mendeteksi adanya penyakit pada dirinya atau orang lain berdasarkan gejala-gejala yang dirasakan dengan menjawab pertanyaan seperti halnya berkonsultasi ke dokter.Sistem pakar ini memiliki banyak metode namun penulis disini mengunakan metode bayes.

\section{LANDASAN TEORI}

2.1 Metode Bayes

Teori keputusan Bayes adalah pendekatan statistik yang fundamental dalam pengenalan pola (pattern recognition)(Hutagalung, Kunci-:, Bayes, \& Pakar, 2015). Metode Bayes ini merupakan metode yang baik didalam mesin pembelanjaran berdasarkan data training, dengan menggunakan probabilitas bersyarat sebagai dasarnya(Hamdani, Studi, \& Informatika, 2016)

Metode ini merupakan salah satu metode untuk mengatasi ketidakpastiannya suatu data. ketidakpastian suatu data. Probabilitas bayes adalah salah satu cara untuk mengatasi ketidakpastian dengan menggunakan formula bayes yang dinyatakan sebagai berikut(Hutagalung et al., 2015):

$$
\mathrm{P}(\mathrm{H} \mid \mathrm{E})=\frac{p(E \mid H) X p(H)}{p(E)}
$$

Dimana :

$\mathrm{P}(\mathrm{H} \mid \mathrm{E})$ :Probabilitas hipotesa $\mathrm{H}$ jika terdapat evidence $\mathrm{E}$

$\mathrm{P}(\mathrm{E} \mid \mathrm{H})$ :Probabilitas munculnya evidence E jika diketahui hipotesa $\mathrm{H}$

$\mathrm{P}(\mathrm{H})$ :Probabilitas hipotesa $\mathrm{H}$ tanpa 
memandang evidence apapun

$\mathrm{P}(\mathrm{E}):$ Probabilitas evidence $\mathrm{E}$ tanpa memandang apapun

Probabilitas menunjukkan kemungkinan sesuatu akan terjadi atau tidak.

$$
\mathrm{P}(\mathrm{x})=\frac{\text { Jumlah Ke jadian Berhasil }}{\text { Jumlah Semua Ke jadian }}
$$

Misal dari 100 orang sarjana Cuma 25 orang yang bisa java. Jadi peluang untuk memilih sarjana yang menguasi java adalaha $P($ java $)=25 / 100=0.25$.

\section{METODE PENELITIAN}

Adapun langkah-langkah melakukan penelitian sebagai berikut :

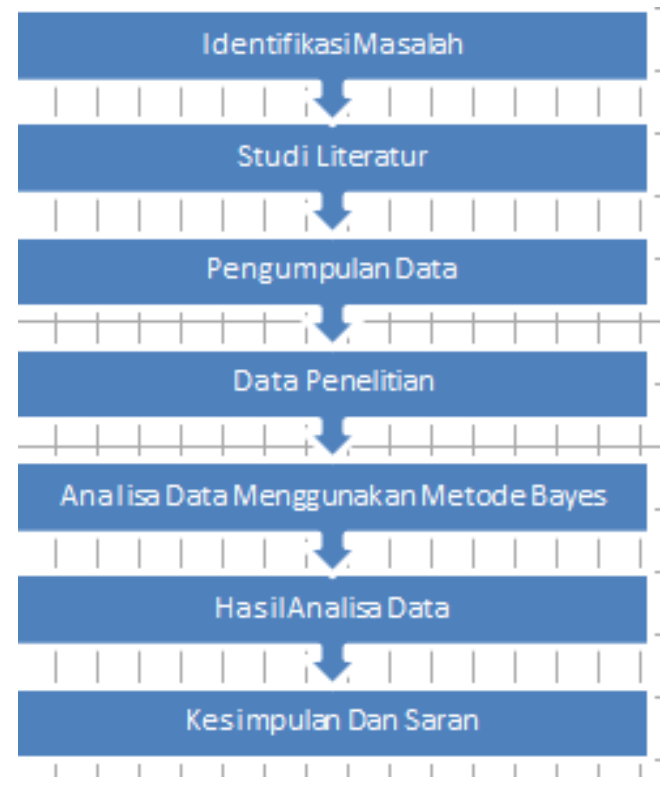

Penjelasan tahapan metodologi penelitan secara umum :

1. Identifikasi Masalah

Melakukan identifikasi masalah merupakan tahapan awal pada setiap proses penelitian. Tahapan ini terjadi berdasarkan rumusan masalah atau latar belakang masalah.

\section{Studi Literatur}

Pada tahapan ini dilakukkan mempelajari serta memahami teori-teori yang digunakan dengan cara membaca buku dan jurnal yang telah ada serta yanga berkaitan.

3. Pengumpulan data

Tahapan ini merupakan cara mengumpulkan data yang diperlukan nantinya. Ada dua cara mengumpulkan data yaitu observasi dan wawancara kepada salah satu Dokter Spesialis Kulit. Untuk mendapatkan gejala penyakit cacar air

4. Data Penelitian

Pengelompokkan data -data yang telah kita dapatkan sebelumnya dari tahap pengumpulan data.

5. Analisa Data Menggunakan Metode Bayes

Pada penelitian ini analisa data menggunakan metode bayes. Dilakukan dengan mengolah data penelitian menggunaka metode bayes dan menghasilkan sebuah informasi yang dapat disimpulkan nantinya.

6. Hasil Analisa Data

Setelah tahapan analisa data menggunakan metode bayes nanti akan dihasilkan suatu hasil analisis yang merupakan hasil dari suatu proses penelitian.

7. Kesimpulan dan Saran

Ini merupakan tahapan terakhir yang dimana kita mengembil hasil kesimpulan.

\section{HASIL DAN PEMBAHASAN}

Adapun hasil yang didapatkan pada tahap penelitian pengumpulan data adalah sebagai berikut : 
Tabel 1 Tabel Gejala Cacar Air

\begin{tabular}{|c|l|}
\hline Kode Gejala & Nama Gejala \\
\hline A1 & Demam \\
\hline A2 & Pusing \\
\hline A3 & Lemas \\
\hline A4 & Nyeri Tenggorokan \\
\hline A5 & Selera Makan Menurun \\
\hline A6 & $\begin{array}{l}\text { Ruam merah,yang } \\
\text { biasanya berawal dari } \\
\text { perut,punggung atau } \\
\text { wajah dan dapat } \\
\text { menyebar ke seluruh } \\
\text { tubuh. } \quad \text { and }\end{array}$ \\
\hline
\end{tabular}

Adapun logika metode teorema bayes pada sesi konsultasi sistem, pengguna konsultasi diberi pilihan jawaban yang masingmasing memiliki bobot sebagai berikut (Hutagalung et al., 2015) :

Tabel 2 Tabel Nilai Bayes

\begin{tabular}{|l|l|}
\hline $\begin{array}{l}\text { Termonologi } \\
\text { Kepastian }\end{array}$ & A/B \\
\hline Tidak Pasti & 0 \\
\hline Tidak Tahu & 0,2 \\
\hline Kurang Pasti & 0,4 \\
\hline Cukup Pasti & 0,6 \\
\hline Hampir Pasti & 0,8 \\
\hline Pasti & 1 \\
\hline
\end{tabular}

Tabel 3 Tabel Presentasi Kesimpulan

\begin{tabular}{|l|l|}
\hline $\begin{array}{l}\text { Tingkat } \\
\text { Presentasi }\end{array}$ & Nilai Kemungkinan \\
\hline $0-30 \%$ & $\begin{array}{l}\text { Sedikit Kemungkinan } \\
\text { atau kemungkinan kecil }\end{array}$ \\
\hline $30-59 \%$ & Kemungkinan \\
\hline $59-79 \%$ & $\begin{array}{l}\text { Besar Kemungkinan atau } \\
\text { Kemungkinan Besar }\end{array}$ \\
\hline $80-100 \%$ & Sangat yakin \\
\hline
\end{tabular}

\section{Contoh Kasus}

Dengan menjawab pertanyaan penyakit cacar air sesuai dengan gejala sebagai berikut :

Demam $/ \mathrm{P}(\mathrm{E} \mid \mathrm{H} 1)=0,8$

Pusing $/ \mathrm{P}(\mathrm{E} \mid \mathrm{H} 2)=0,3$

Lemas $/ \mathrm{P}(\mathrm{E} \mid \mathrm{H} 3)=0,6$

Nyeri Tenggorokan $/ \mathrm{P}(\mathrm{E} \mid \mathrm{H} 4)=0,4$

Selera Makan Menurun $/ \mathrm{P}(\mathrm{E} \mid \mathrm{H} 5)=0,5$

Ruam Merah $/ \mathrm{P}(\mathrm{E} \mid \mathrm{H} 1)=0,8$

Selanjutnya mencari semesta dengan menjumlahkan hipotesa diatas :

$$
\begin{aligned}
& \sum_{k=1}^{n}=\mathrm{A} 1+\mathrm{A} 2+\mathrm{A} 3+\mathrm{A} 4+\mathrm{A} 5+\mathrm{A} 6 \\
= & 0,8+0,3+0,6+0,4+0,5+0,8 \\
= & 3,4
\end{aligned}
$$

Setelah hasil penjumlahan diatas diketahusi,selanjutnya maka didapatkan rumus yang akan menghitung nilai semesta sebagi berikut :

$$
\begin{gathered}
P(H \mid 1)=\frac{P(H 1)}{\sum_{k=1}^{1}=0,2352941176} \frac{0,8}{3,4} \\
P(H \mid 2)=\frac{P(H 2)}{\sum_{k=1}^{2}}=\frac{0,7}{3,4} \\
=0,2058823529 \\
P(H \mid 3)=\frac{P(H 1)}{\sum_{k=1}^{3}=\frac{0,6}{3,4}=0,2083333} \\
P(H \mid 4)=\frac{P(H 1)}{\sum_{k=1}^{4}}=\frac{0,4}{3,4}=0,125 \\
P(H \mid 5)=\frac{P(H 1)}{\sum_{k=1}^{5}}=\frac{0,5}{3,4}=0,125 \\
P(H \mid 6)=\frac{P(H 1)}{\sum_{k=1}^{6}}=\frac{0,8}{3,4}=0,3333333
\end{gathered}
$$

Setelah nilai $\mathrm{P}(\mathrm{Hi})$ diketahui, probabilitas 
hipotesis $\mathrm{H}$ tanpa memandang Evidence apapun, maka langkah selanjutnya adalah :

$$
\sum_{k=1}^{n}=\mathrm{P}(\mathrm{Hi}) \times \mathrm{P}(\mathrm{E} \backslash \mathrm{Hi}-\mathrm{n})
$$

$=\mathrm{P}(\mathrm{H} 1) *(\mathrm{P}(\mathrm{E} \mid \mathrm{H} 1))+\mathrm{P}(\mathrm{H} 2) *(\mathrm{P}(\mathrm{E} \mid \mathrm{H} 2)+\mathrm{P}($ $\mathrm{H} 3)^{*}\left(\mathrm{P}(\mathrm{E} \mid \mathrm{H} 3)+\mathrm{P}(\mathrm{H} 4) *\left(\mathrm{P}(\mathrm{E} \mid \mathrm{H} 4)+\mathrm{P}(\mathrm{H} 5)^{*}\right.\right.$ $(\mathrm{P}(\mathrm{E} \mid \mathrm{H} 5)+\mathrm{P}(\mathrm{H} 6) *(\mathrm{P}(\mathrm{E} \mid \mathrm{H} 6)$

$=(0,2352941176 * 0,8)+(0,2058823529 * 0,7$ )$+(0,1764705882 * 0,6)+(0,11764705882 * 0$ ,4) $+(0,1470588235$

$* 0,5)+(0,2352941176 * 0,8)$

$=0,1882352941+0.144117647$

$+0,1058823529+0,0705882353+0,073529$

$4118+0,1882352941$

$=0,7705882352$

Langkah selanjutnya adalah mencari nilai $\mathrm{P}(\mathrm{HilE})$ atau probabilitas hipotesis $\mathrm{Hi}$ benar jika diberikan evidence $\mathrm{E}$.

$$
\begin{aligned}
& P(H 1)=\frac{P(E \backslash H i) * P(H i)}{\sum_{k=1}^{n} P(E \backslash H i) * P(H i)} \\
& P(H 1 \backslash E)=\frac{0,8 \times 0,2352941176}{0,7705882352} \\
& =0,2442748092 \\
& P(H 2 \backslash E)=\frac{0,7 \times 0,2058823529}{0,7705882352} \\
& =0,1870229007 \\
& P(H 3 \backslash E)=\frac{0,6 \times 0,1764705882}{0,7705882352} \\
& =0,1374045801 \\
& P(H 4 \backslash E)=\frac{0,4 \times 0,11764705882}{0,7705882352} \\
& =0,0610687023 \\
& P(H 5 \backslash E)=\frac{0,5 \times 0,1470588235}{0,7705882352} \\
& =0.0954198473
\end{aligned}
$$

$$
\begin{array}{r}
P(H 6 \backslash E)=\frac{0,8 \times 0,2352941176}{0,7705882352} \\
=0,2442748091
\end{array}
$$

$=0,2442748092+$

$0,18702290070,1374045801+$

$0,0610687023+0.0954198473+$

0,2442748091

$=0,969465655$

$=96,947 \%$

Dari hasil perhitungan diatas dapat dipastikan pastikan pasien terdiagnosa penyakit cacar air dengan probabilitas $=96,947 \%$

\section{SIMPULAN DAN SARAN}

Adapun kesimpulan yang penulis peroleh berdasarkan hasil perancangan aplikasi ini adalah sebagai berikut :

1. Sistem pakar untuk mendiagnosis penyakit cacar air dengan metode bayes ini mampu memberikan informasi kepada pengguna mengenai diagnosa penyakit yang diderita berdasarkan gejalagejala yang diberikan layaknya berkonsulatasi dengan dokter.

2. Sistem pakar hanya dapat mendiagnosa penyakit cacar air saja.

3. Dengan metode bayes dalam mendiagnosa penyakit cacar air , dapat menunjukan besarnya nilai kepercayaan terhadap hasil diagnosa.

\section{DAFTAR PUSTAKA}

Hamdani, R., Studi, P., \& Informatika, M. (2016). Penerapan Metode Bayes Dalam Mendiagnosa Gangguan Perkembangan Pada Anak. 20(1), 69-73.

Hutagalung, N. A., Kunci-:, K., Bayes, M., 
\& Pakar, S. (2015). Implementasi Metode Bayes Pada Sistem Pakar Mendiagnosa Penyakit Polio. Jurnal Sistem Informasi Dan Komputerisasi Akuntansi), 01(02), 26-30. Retrieved from http://www.jsk.ac.id

Nasution, Y. R., \& Khairuna. (2017). Sistem pakar deteksi awal penyakit tuberkulosis dengan metode bayes. Klorofil, 1(1), 17-23.

Warini, E., \& Sunyoto, A. (2017). Sistem Pakar Untuk Diagnosa Penyakit Cacar Air Pada Anak Menggunakan Metode Certainty Factor. International Conference on Information and Knowledge Management, Proceedings, Part F1318, 919-928. https://doi.org/10.1145/3132847.3132 886 